\title{
Regional Flood Forecasting using SWMM for Urban Catchment
}

\author{
S. Sri Harsha, Sunny Agarwal, C Hari Kiran
}

\begin{abstract}
Urban flooding is the inundation of land or property in a designed atmosphere, significantly in additional densely inhabited areas, caused by precipitation overwhelming the capability of drain systems, like storm sewers. Due to expeditious increment and improper urban designing the probabilities of creek, localized or flash urban floods have drastically multiplied. This study explores the application of Storm Water Management Model (SWMM) to densely populated area of Vijayawada city, which is fragmented into 58 sub-catchments. The study area is delineated in SWMM by the assistance of blueprint AutoCAD maps showing drainage network and Reference Level details. From this elaborated elevation data of drain networks, the flow direction has been evaluated to create the descriptive view of the area in SWMM. In this study area 2016, 2017 and 2018 extreme rainfall events of 24 hrs interval is considered for runoff analysis. The focus of the current wok is to model runoff conditions by applying Dynamic wave equation for routing floods and Green-Ampt equation for infiltration in SWMM. The model outputs guided in visualizing the runoff from extreme precipitation events and to analyze the accuracy of the storm water network system.
\end{abstract}

Keywords: AutoCAD, Flash Floods, Sub catchments, SWMM, Reduced levels, Green-Ampt infiltration model, Dynamic wave.

\section{INTRODUCTION}

India is highly vulnerable to various natural disasters such as, Floods, Cyclones, Droughts, Landslides, etc. Among which flooding situation is very much disastrous as it can cause widespread loss of life and property. Mostly the regions occupying Haryana, North Bihar, West Bengal and some portions of Uttar Pradesh along with coastal belt regions of Andhra Pradesh, Gujarat and Orissa are predominantly affected by floods. The districts of Krishna, Guntur( Krishna river), West and East Godavari (Godavari river) along with cities and towns like Vijayawada, Guntur (Krishna river), Eluru, Machilipatnam, Bhimavaram, Rajahmundry, Kakinada(Godavari river) and some parts of Nellore(Penna river) on the east coast has been marked as Flood hazard zones map issued by National Disaster Management Authority (NDMA).In this study, we have considered the area of densely populated area of Vijayawada city, Andhra Pradesh. Primarily flooding may be considered

Revised Manuscript Received on February 05, 2020.

* Correspondence Author

S. Sri Harsha*, M-Tech Student, Civil Engineering Department, Koneru Lakshmaiah Education Foundation, Vaddeswaram, Guntur, Andhra

Pradesh, India - 522502.

Sunny Agarwal, Assistant Professor, Civil Engineering Department, Koneru Lakshmaiah Education Foundation, Vaddeswaram, Guntur, Andhra Pradesh, India - 522502.

C.H. Hari Kiran, Project Manager, (DM), APSDMA, India.

(C) The Authors. Published by Blue Eyes Intelligence Engineering and Sciences Publication (BEIESP). This is an open access article under the CC BY-NC-ND license (http://creativecommons.org/licenses/by-nc-nd/4.0/)

as a natural phenomenon which has some added benefits but due to human interventions in the flood plain region it is causing tremendous devastation to the livelihood of people [1].

In the past four decades the town because of its increasing population has converted into the flood plains. Flooding is common within the city. Urban flooding leads to insufficient carrying capacity of storm drains, blockages of storm drain due to solid waste, which results in increment of the flood peak from 1.8 to 8 times and volume of flood approximately 6 times. More often it is observed that Urban flooding is occurring very rapidly within the range of few minutes due to the faster flowtimes [2]. Construction of Pavements, Roads, Parking Lots, Houses increases the impervious cover and reduce the infiltration, it is the main cause of the urban floods. Due to the coverage of land features with impervious surfaces chances of conversion of precipitation to runoff increased to manifolds. Unplanned development and encroachments of sprawling habitations aboard rivers and watercourses have meddled with the natural streams and watercourses. Hence, the runoff increased in proportion with respect to Urbanization causing Urban Floods. Thus, urban flood management of should be considered with top priority.

Different models are developed for estimation of Urban runoff like Mike Urban, Mike Flood, Hydrologic Engineering Centers-River Analysis System (HEC-RAS), among which EPA-SWMM is given by Environmental Protection Agency. In case of MIKE URBAN model, the two-dimensional flow routing can be done during an extreme rainfall event occurring in short period which results in the flooding of drainage [3]. To control flooding situations Storm Management is done by diverting the flow of excess water. These techniques helps in attaining sustainable development without increasing the vulnerability to flood [4].

The Land Surface that is delineated through Sub catchments. It is getting precipitation from the Atmosphere within the sort of rainfall and it sends outflow within the kind of infiltration to the bottom levels and additionally as surface runoff and waste material loadings to the Transportation. The Transportation contains a network of conveyance elements like channels, pipes, pumps, and regulators. Inflows to the current compartment will return from surface runoff.

Inflows to the current compartment will return from surface runoff. The elements of the Transportation area unit sculptured with Nodes, Junctions, Outfalls, storage/treatment units, Links, conduits, pumps, outlets. Rain Gages provide precipitation information for sub catchment areas in an exceedingly study region. The area is divided into various Sub catchments into permeable and imperviable sub catchments. The Surface runoff is infiltrating mainly to higher soil root zone depth of the surfaces which are permeable in nature instead of area which is impervious.

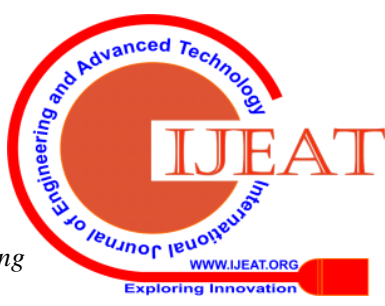




\section{Regional Flood Forecasting using SWMM for Urban Catchment}

The impervious area is further divided into two units mainly one with depression storage and another lacking that. Runoff can be due to one sub catchment area during a rainfall event will be routed to the another subarea, or each subarea will drain to the sub catchment outlet.

As per Florida Department of Environmental Protection (FDEP), the rainfall occurring in pervious area there will contribute to average evaporation of $50 \%$, surface runoff entering to nearby water bodies as $30 \%$ and nearly $20 \%$ will undergo infiltrate and contribute as Ground water reserve [5]. Infiltration of precipitation from the permeable space of a sub catchment into the unsaturated higher soil zone is represented exploitation four completely different models: Horton infiltration, modified Horton infiltration, Green-Ampt infiltration, modified Green-Ampt infiltration and Curve number infiltration. Flow routing contains three methods for the discharge of runoff Steady Flow, Kinematic Wave, Dynamic wave [6]. The present study is mainly focusing on runoff through Urban sub catchments of Vijayawada City, Andhra Pradesh, India where the excess runoff is a major concern to the environment due to dense population [7].

\section{STUDY AREA}

The study area is lying between $16.50 \mathrm{~N}$ Latitude and $80.64 \mathrm{E}$ Longitude of Krishna district in A.P. having geographical spread area of $62 \mathrm{Sq}$. Km. The town is that the second largest city within the state by population and third most densely inhabited urban settled areas within the world. Vijayawada city is lying at the top of the Krishna delta which is nearly 70 $\mathrm{km}$ away from ocean and encircled by Indrakiladri Hills on the west while Budameru stream on the north. The land of town of Vijayawada is regarding thirty-nine feet on top of the ocean level. Majorly three Canals namely Ryves, Eluru and Bandar is incepting from reservoir beneath Prakasam barrage.

\section{Topography:}

It is the most crucial feature of Geographic landscape of Vijayawada city. It is mainly dominated by undulating hillocks which are tiny and medium sized and comprised of intensive plain lands between them.

\section{Climatology:}

The city is having Tropical type of Climate having hot summers \& moderate winters. The temperature rising to 47 ${ }^{\circ} \mathrm{C}$ in June, while winter temperature is ranging from 20 to 27 ${ }^{\circ} \mathrm{C}$. The climate of Vijayawada is also marked by a considerable amount of rain fall. The common humidity is $78 \%$ and also the average annual rain fall is $103 \mathrm{~cm}$. Vijayawada gets its rainfall from each the south- west monsoon and north-east monsoon. Cyclones are also pretty common in the Vijayawada climate. The location map of Vijayawada is shown in Fig. 2 shows boundaries of the study space that shows landform is undulating that is appropriate for investigation and finding out.

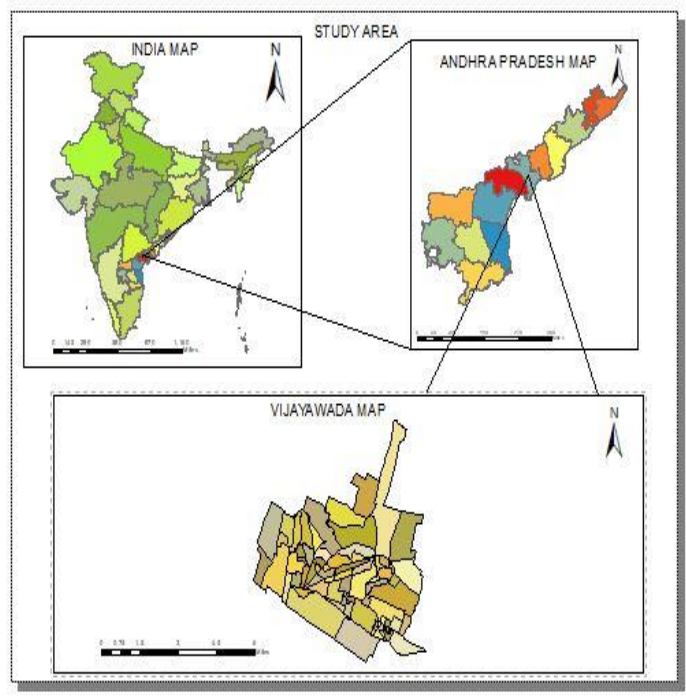

Fig - 1 Study area representation as ARC-GIS map

\section{DATA REQUIREMENTS}

The base map of Vijayawada has been collected from the Andhra Pradesh Township and Infrastructure Development corporation (APTIDCO). Strom Water Network data of Vijayawada has been collected form Vijayawada Municipal corporation (VMC). Daily Rainfall data of 2016, 2017, 2018 has been collected from Andhra Pradesh State Disaster Management Authority (APSDMA). Sentinel data has been downloaded from United States Geological Survey (USGS) for making LULC map of the area.

\section{METHODOLOGY}

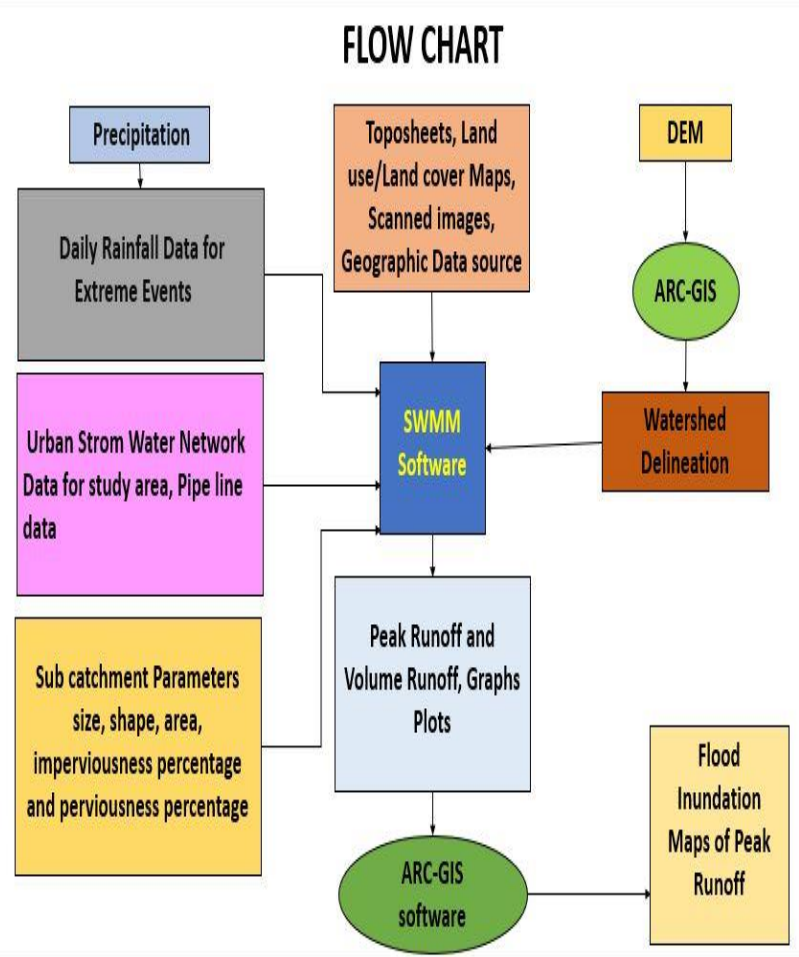

Fig - 2 Flowchart of process in SWMM 
Above Flowchart represent the inputs and process of SWMM model. By the collection of AUTOCAD map of study area the sub catchments are extracted and imported to SWMM by converting base map to image file. Then numerous Junctions are added to the sub catchments and then various Conduits are added to join these Junctions. Various input parameters like Invert levels, Depth, Slope, Imperviousness, Area, roughness etc. are defined in the model. The Model building method in SWMM involves series of operations in varied range of datasets that is being described by Fig -2. In SWMM each sub catchments Invert levels and depth are given according to the storm water network map of Vijayawada city.

The imperviousness and slope of particular sub catchments are given according to the preparation of Land use Land cover map which was prepared from Sentinel data. This data is used to develop LULC and slope map of the region. Area of each sub catchments has been given according to the measurement option provided in SWMM itself. Daily Rainfall data of 2016, 2017, 2018 has been analyzed and given input to the rain gauge section of the model. The study area is represented in SWMM as in the below Fig - 3 layout of study area in SWMM. Thus, schematic illustration of the study space is well defined in SWMM with all elements to model Urban Flood. Model output is portrayed by statistic, Profile \& Scatter Plots.

Table-1 Manning's n - Overland Flow

\begin{tabular}{|l|l|}
\hline Surface & $\mathbf{n}$ \\
\hline Smooth asphalt & 0.011 \\
\hline Smooth concrete & 0.012 \\
\hline Ordinary concrete lining & 0.013 \\
\hline Good wood & 0.014 \\
\hline Brick with cement mortar & 0.014 \\
\hline Vitrified clay & 0.015 \\
\hline Cast iron & 0.015 \\
\hline Corrugated metal pipes & 0.024 \\
\hline Cement rubble surface & 0.024 \\
\hline Fallow soils (no residue) & 0.05 \\
\hline Cultivated soils & 0.06 \\
Residue cover < 20\% & 0.17 \\
\hline Residue cover $>20 \%$ & 0.13 \\
\hline Range (natural) & 0.15 \\
\hline $\begin{array}{l}\text { Grass } \\
\text { Short, prairie } \\
\text { Dense } \\
\text { Bermuda grass }\end{array}$ & 0.24 \\
\hline Woods & 0.41 \\
\hline Dight underbrush & 0.40 \\
\hline
\end{tabular}

Source: McCuen, R. et al. (1996), Hydrology, FHWA-SA96-067, Federal Highway Administration, Washington, DC.

This Table-1 represents the N-pervious and impervious values depending on the land type as mentioned. According to the Standard values the Manning's constant is defined in the model for different land classes. Further sub catchment discretization task is done in SWMM to represent each individual sub catchments. The runoff generated through each sub catchments has been routed to various nodes which are spatially configured in the model. Numerous links are used to connect these nodes to route the flow to various outlets which are lying at lowermost elevation of the area. The flow occurring through this conduit are governed by Gravity forces from higher to lower levels.

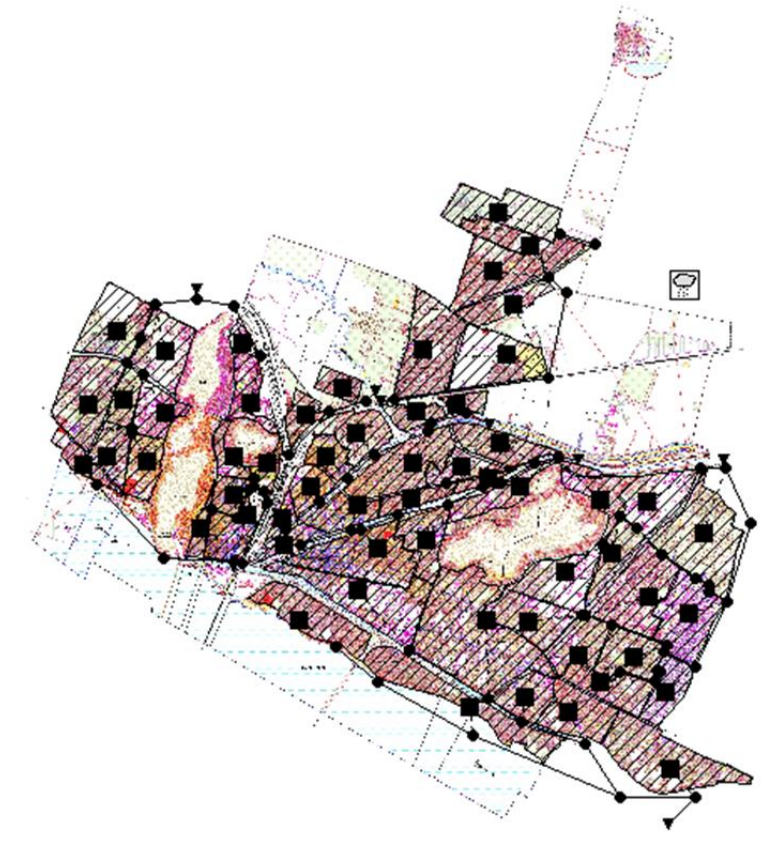

Fig -3 Layout of study area in SWMM

\section{A. MODEL SETUP}

The entire geographical study area of Vijayawada has been fragmented into 58 sub catchments and Nodes which are 76 in number for whole study area which connects to the conduits total 75 and further they are connected to the 8 outlets to discharge the runoff. The runoff percolates from each individual sub catchments to the nodes and discharge to outlets through the conduits. Extreme precipitation events of 2016, 2017 and 2018 has been taken as inputs to run the model in SWMM. For the infiltration Modified Green-Ampt method has been applied and simultaneously for flow routing Dynamic wave method has been applied for analysis of surface runoff from various sub catchments.

\section{RESULT AND DISCUSSION}

It has been visualized that SWMM has moderately computed runoff for 3 years i.e 2016, 2017 and 2018 extreme precipitation events. The runoff which is generated from the sub catchments has been plotted in the form of graphs for different rainfall events as represented in the Fig-4, 5 and 6 respectively. It is ascertained that the SWMM has generated the peak runoff for the three totally different extreme precipitation events of 2016, 2017 and 2018 rainfall events. 


\section{Regional Flood Forecasting using SWMM for Urban Catchment}

These graphs helps in understanding the precipitation relationship for Runoff of each sub catchments with reference to numerous precipitation events in impervious and permeable surface runoff.

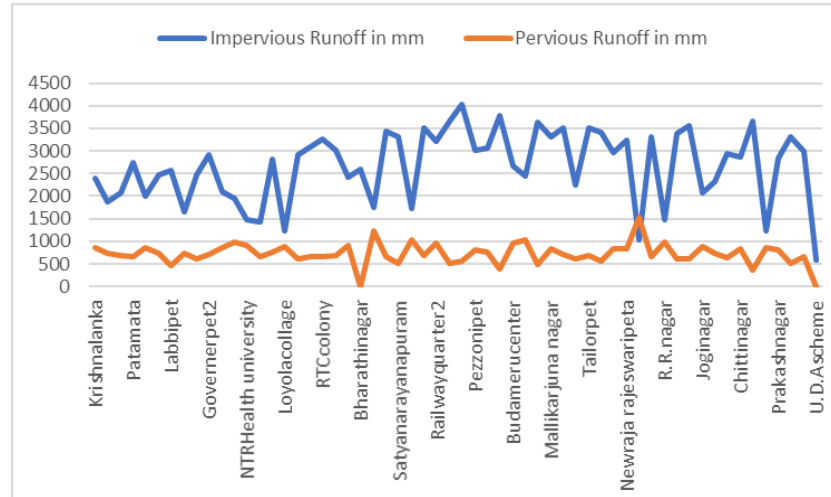

Fig-4 Runoff from Impervious Vs Pervious area for 2016 rainfall events

This graph of Fig-4 represents the relationship of the impervious runoff and pervious runoff which is obtained from the sub - catchments for the extreme precipitation events of the year 2016.

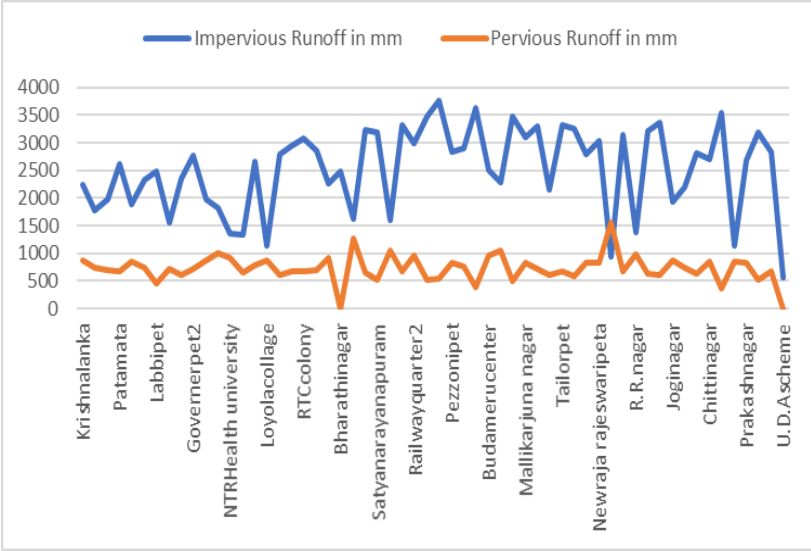

Fig-5 Runoff from Impervious Vs Pervious area for 2017 rainfall events.

This graph of Fig-5 represents the relationship of the impervious runoff and pervious runoff which is obtained from the sub - catchments of the study area for the extreme precipitation events of the year 2017.

Table -2 Outfall Loading

\begin{tabular}{|ccccc|}
\hline Outfall & Flow freq. \% & $\begin{array}{c}\text { Avg Flow } \\
\text { CMS }\end{array}$ & $\begin{array}{c}\text { Max Flow } \\
\text { CMS }\end{array}$ & $\begin{array}{c}\text { Total } \\
\text { Volume } \\
\text { 10^6 ltr }\end{array}$ \\
\hline $\mathbf{5 9}$ & 99.94 & 1.363 & 1.377 & 3413.672 \\
$\mathbf{7 2}$ & 99.92 & 2.11 & 2.138 & 5285.747 \\
$\mathbf{7 3}$ & 99.9 & 1.579 & 1.602 & 3954.254 \\
$\mathbf{7 4}$ & 99.94 & 2.382 & 2.437 & 5972.91 \\
$\mathbf{7 7}$ & 99.95 & 2.46 & 2.505 & 6166.223 \\
$\mathbf{7 8}$ & 99.93 & 1.783 & 1.823 & 4470.132 \\
$\mathbf{8 4}$ & 99.91 & 0.963 & 0.991 & 2416.05 \\
$\mathbf{8 8}$ & 99.86 & 2.16 & 2.196 & 5408.664 \\
\hline
\end{tabular}

This Table - 2 represents the different outfalls showing flow frequency in percentage, average flow in CMS, Max Flow in
CMS and also Total Volume in litres which the SWMM produced from the extreme rainfall event of the year 2018.

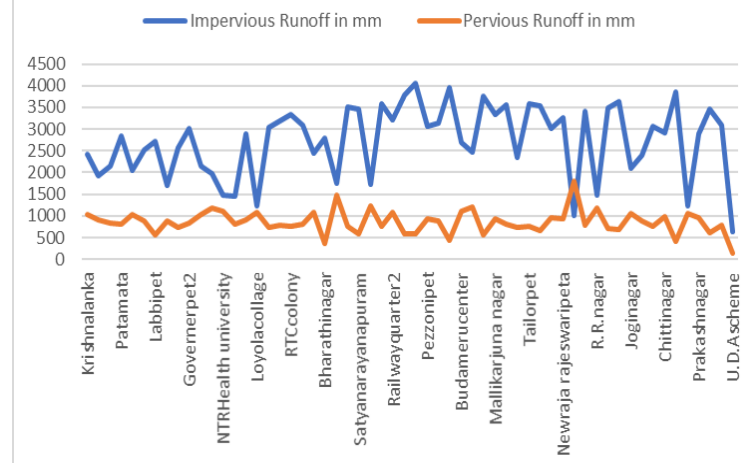

Fig-6 Runoff from Impervious Vs Pervious area for 2018 rainfall events.

This graph of Fig-6 represents the relationship of the impervious runoff and pervious runoff which is obtained from the sub catchments of the study area for the extreme precipitation events of the year 2018.

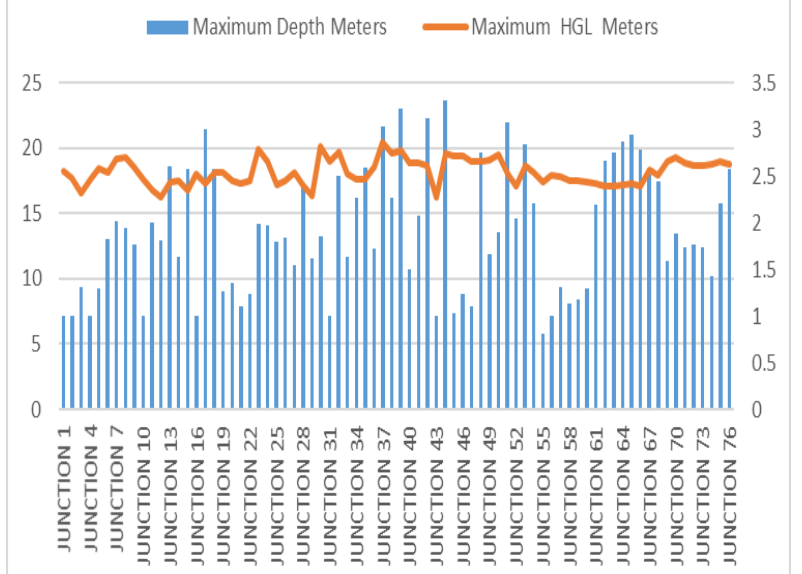

Fig-7 Maximum depth Vs Maximum HGL (Node Depth)

This graph of Fig-7 represents the relationship of the maximum depth and maximum HGL in meters which represents Hydraulic Gradient Line.

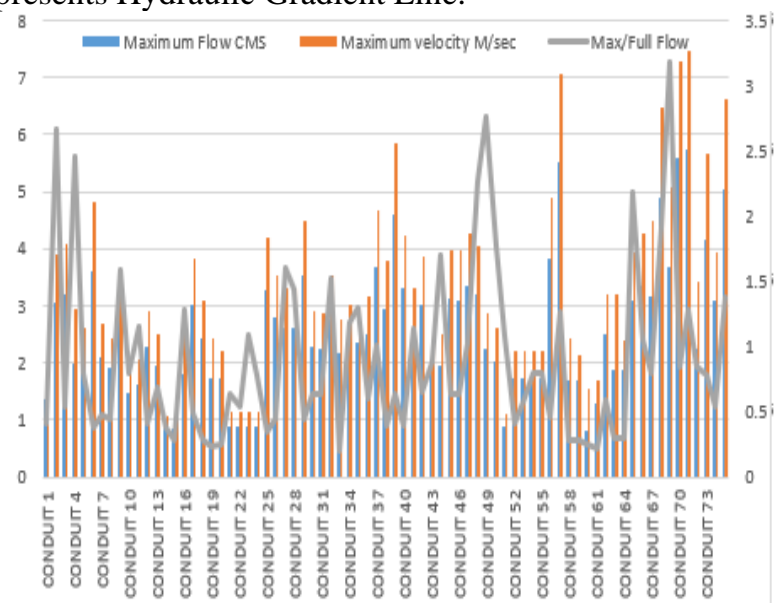

Fig-8 Variability of Maximum Flow, Velocity and Full Flow This graph of Fig-8 represents the relationship of the Maximum Flow in CMS, Maximum Velocity in $\mathrm{m} / \mathrm{sec}$ and Max/Full Flow.

\section{Published By:}




\section{CONCLUSION}

The case study work out the present analysis of runoff for the densely populated area of Vijayawada which has been proven that SWMM is compatible for modeling and management of Urban flood conditions. It is an appropriate tool for modeling Urban Flood situations and regarded terribly user friendly because of its result interpretation techniques within the type of Graphs, statistical plots, tables etc. Various input parameters like impermeability and penetrability of a locality together with coefficient of roughness will adhere dynamism capability in densely populated area. The impermeability and penetrability are given relevantly consistent with the land use land cover map prepared with the sentinel information and therefore the roughness coefficients and regarded consistent with the literature review as described within the Table-1 Manning's n - Overland Flow. The result is generated from the three extreme daily precipitation events during 2016, 2017 and 2018, thus, the graphs are also plotted accordingly. As per the suitability of the technique to compute impervious and pervious cover of an urban area the results of the model will be more reliable. Presently appropriate values of Imperviousness and Slope of the subcatchments have considered by preparing the land use land cover and slope map from recent data. The results obtained from the model is mainly the peak runoff, volume of runoff, Impervious/Pervious surface runoff, Maximum depth \& HGL, Maximum Flow velocity, Flow Frequency, Average Flow and Total Volume of runoff from each Sub catchments.

\section{REFERENCES}

1. S. Agarwal and S. Kumar, "Applicability of SWMM for Semi Urban Catchment Flood modeling using Extreme Rainfall Events," Int. J. Recent Technol. Eng., vol. 8, no. 2, pp. 245-251, 2019.

2. S. M. F. Ahamed and S. Agarwal, "Urban flood modeling and management using SWMM for new R.R. pet region, Vijayawada, India," Int. J. Recent Technol. Eng., vol. 7, no. 6C2, pp. 317-322, 2019.

3. D. S. Bisht, C. Chatterjee, S. Kalakoti, P. Upadhyay, M. Sahoo, and A. Panda, "Modeling urban floods and drainage using SWMM and MIKE URBAN: a case study," Nat. Hazards, vol. 84, no. 2, pp. 749-776, 2016.

4. Laddimath, R. S. (2016). Sustainable Development of Storm Water Management using SWMM for Bhagyanagar, Belagavi. 3(02), 488-493

5. Florida Smart (2006). "Florida Climate- Seasons in Florida," Retrieved February 10, 2010. Florida Smart Web guide.

6. Huber, W. C., and Dickinson, R. E. (1988). Storm water management model, user's manual, version 4.0, EPA-600/3-88-001a. U.S. Environmental Protection Agency, Athens, GA

7. P. Sundara Kumar, T. Santhi, P. Manoj Srivatsav, S. V. Sreekanth Reddy, M. Anjaneya Prasad, and T. V. Praveen, "Storm water drainage design (Case study Vijayawada)," Int. J. Earth Sci. Eng., vol. 8, no. 2, pp. 507-511, 2015.

8. Girish, D., \& Agarwal, S. (2019). Utilization of Storm Water Management Model for Urban Flood Scenario. (2), 3716-3721. https://doi.org/10.35940/ijeat.B3928.129219

9. Rao, B. S. P. (2011). Run-off and flood estimation in Krishna River Delta using Remote Sensing \& GIS. (April).

10. S. Vemula, K. S. Raju, S. S. Veena, and A. S. Kumar, "Urban floods in Hyderabad, India, under present and future rainfall scenarios: a case study,” Nat. Hazards, vol. 95, no. 3, pp. 637-655, 2019.

11. Babu, K. V. S., Reddy, K. R., Kumar, K. S., \& Vishwanadham, P. K. (2019). Water Resources Development and Management in Sub - Basin using Geospatial Technologies: A Case Study. (6), 639-642.

12. Surwase, T., \& Manjushree, P. (2019). Urban Flood Simulation -a Case Study of Hyderabad city. National Conference on Flood Early Warning for Disaster Risk Reduction, (June), 133-143.

13. Agarwal, S., Patil, J. P., Goyal, V. C., \& Singh, A. (2018). Assessment of Water Supply-Demand Using Water Evaluation and Planning (WEAP) Model for Ur River Watershed, Madhya Pradesh, India. Journal of The Institution of Engineers (India): Series A https://doi.org/10.1007/s40030-018-0329-0
14. Bhowmick, S., Dey, P. D. A., \& Khan, S. M. (2018). Assessment of Storm Water Runoff with Arc-Swat and Swmm in Mymensingh District. 2018(December), 19-21.

15. Reshma, T., \& Pratap, D. (2014). Optimization of Manning's Roughness Coefficients for a watershed using Multi- Objective Genetic Algorithm. (February 2015).

16. Kusuma, S., \& Pradesh, A. (2016). Land Use and Land Cover change detection and urban sprawl analysis of Vijayawada city using multitemporal Landsat. (January 2012).

17. Devi, K. N. V. R., Ramana, R. V., Rao, Y. R. S., \& Kumar, S. (2019) Development of Data Driven Rainfall - Runoff Model for the Sarada River Basin. (6), 508-512.

\section{AUTHORS PROFILE}

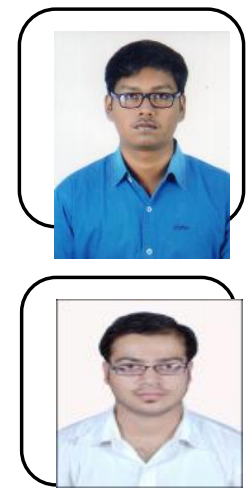

S. Sri Harsha, has completed B-tech in Civil Engineeering form Gokaraju Rangaraju Institute of Engineering and Technology, Hyderabad. He is pursuing M-Tech (II nd Year) in Geo-Informatics, Civil Engineering Department from Koneru Lakshmaiah Education Foundation, Vaddeswaram, Guntur.

Sunny Agarwal, has completed Integrated MTech in Water Engineering and Management from Central University of Jharkhand, Ranchi. He is pursuing Ph.D. and working as Assistant Professor at KLEF, Civil Dept., Guntur, A.P., India. He has published four research papers one in International referred Journal (The Institution of Engineers: Series A-Springer), two in International Journal of Recent Technology and Engineering (IJRTE) and recently one in International Journal of Engineering and Advanced Technology (IJEAT). Also, he has published one book in Lambert Academic Publishing. His area of interest is Urban Flooding, Hydrological modeling, RS \& GIS applications etc.

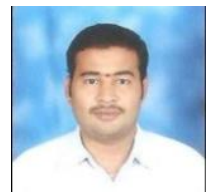

C Hari kiran, has completed M-Tech in Space Technology and application from S V University, Tirupathi. He is working as Project Manager at APSDMA Guntur, A.P since December 2017. He has published one research paper in International Referred Journal 10.1007/s00704-013-1049-z, Springer-Verlag Wien 2013. He worked as Young Professional in APSDPS from 2012 -2017. His area of specialization is Water Resources with a focus on Climate change impacts on Hydrology, Statistical downscaling of GCM outputs and Reservoir operation for adaptation to Climate Change. 